\title{
Isotopic indices as a measure of inflammation in rheumatoid arthritis
}

\author{
H. BERRY AND E. C. HUSKISSON \\ From St. Bartholomew's Hospital, London
}

Assessment of inflammation in rheumatoid arthritis (RA) has been studied in several different ways. Hart and Huskisson (1972) considered morning stiffness to be a reflection of inflammation with the disadvantage of being subjective. Boardman and Hart (1967) used proximal interphalangeal joint circumference which is at least objective, but may not be responsive to anti-inflammatory therapy, for example in patients with long-standing or 'burnt-out' disease.

Dick, Neufeld, Prentice, Woodburn, Whaley, Nuki, and Buchanan (1970) found that external count rates over single inflamed joints were greater than those over normal joints. They used technetium $99\left({ }^{99} \mathrm{Tc}\right)$, an isotope with a half-life of 6 hours, and showed reduction in counts after treatment with anti-inflammatory drugs. In a previous study, Huskisson, Berry, Browett, and Balme (1973) showed, no relationship between technetium count over a single joint and any other measurement, arguing that reduction in count rate over a single joint could not be equated with anti-inflammatory effect. These authors also used an index based on counts over both wrists and knees, and in a small study there was a significant correlation with articular index.

Though highly protein bound, ${ }^{99} \mathrm{Tc}$ is presumably distributed to some extent in the extravascular extracellular space. Huskisson and others (1973) showed, by simultaneous counting of a blood sample and of soft tissues over the forearm, that ${ }^{99} \mathrm{Tc}$ tended to remain more within the vascular compartment in patients with rheumatoid arthritis than in normals. Since most authors have suggested that ${ }^{99} \mathrm{Tc}$ measures 'vascularity', an isotope which remains entirely within the circulation might be more useful for this purpose. In this study, Indium $113\left({ }^{113} \mathrm{In}\right)$, a gamma emitter with a half-life of 99.5 minutes, was used. It is believed that it remains almost entirely within the circulation (Stern, Goodwin, Scheffel, Wagner, and Kramer, 1967). The ${ }^{113} \mathrm{In}$ and ${ }^{99} \mathrm{Tc}$ indices have been compared and their responsiveness to anti-inflammatory therapy assessed.

Accepted for publication April 25, 1974.

\section{Methods}

1 INJECTION OF ISOTOPE AND MEASUREMENTS In all studies approximately $200 \mu \mathrm{Ci}$ isotope was injected intravenously. The syringe was counted before and after injection; the dose of isotope was obtained by subtracting the counts for the syringe after injection from the counts before injection. ${ }^{99} \mathrm{Tc}$ and ${ }^{113} \mathrm{In}$ indices were calculated by dividing the total counts for four joints by the dose of isotope given. In a preliminary study, peak count rates over joints were reached within 15 mins after injection of both ${ }^{99} \mathrm{Tc}$ and ${ }^{113} \mathrm{In}$. External counts were therefore carried out 15 mins after injection of isotope. Both knees and both wrists were counted, each joint for $20 \mathrm{sec}$, with the patient supine and the counter just touching the skin. Repositioning error was $2.3 \%$ compared to a counting error of $0.8 \%$

2 STUDY OF NORMAL PATIENTS

${ }^{113}$ In and ${ }^{99} \mathrm{Tc}$ indices were measured in seven normal volunteers.

3 STUDY OF PATIENTS WITH RA

${ }^{113}$ In index was measured in twenty-nine patients, and ${ }^{99} \mathrm{Tc}$ index in thirty patients with classical or definite RA by the A.R.A. criteria (Committee of the American Rheumatism Association, 1959). The patients were taking only placebo or simple analgesics, all anti-inflammatory therapy having been stopped at least 1 week before the start of the study. Articular index was measured at the same time using the method of Ritchie, Boyle, McInnes, Jasani, Dalakos, Grieveson, and Buchanan (1968).

4 DOUBLE BLIND CROSS-OVER STUDY OF PREDNISOLONE AND PLACEBO IN PATIENTS WITH RA Twelve patients with active rheumatoid arthritis were admitted to this study. Details of these patients are shown in Table I. In the 1st week they received either prednisolone $15 \mathrm{mg}$ daily or identical placebo. At the end of the first week there was a 'wash-out' period of 1 week to allow for full excretion of the drug. During the third week, the patients crossed over to the second treatment. The ${ }^{99} \mathrm{Tc}$ and ${ }^{113}$ In indices were measured at the end of the first and third weeks of the study, at the same time as conventional measures of disease severity, including joint size (Boardman and Hart, 1967), articular index (Ritchie and others, 1968), morning stiffness, and pain by means of the visual analogue scale (Berry and Huskisson, 1972). During the study, the patients were also allowed paracetamol and tablets returned were counted. Patients were asked at the end of the study which treatment period they preferred. 
Table I Details of patients studied after one week of therapy with paracetamol only

\begin{tabular}{|c|c|c|c|c|}
\hline Case no. & $\begin{array}{l}\text { Age } \\
\text { (yrs) }\end{array}$ & Sex & $\begin{array}{l}\text { Duration } \\
\text { of disease } \\
\text { (yrs) }\end{array}$ & $\begin{array}{l}\text { Articular } \\
\text { index* }\end{array}$ \\
\hline $\begin{array}{r}1 \\
2 \\
3 \\
4 \\
5 \\
6 \\
7 \\
8 \\
9 \\
10 \\
11 \\
12\end{array}$ & $\begin{array}{l}64 \\
62 \\
74 \\
64 \\
69 \\
35 \\
58 \\
69 \\
45 \\
62 \\
45 \\
50\end{array}$ & $\begin{array}{l}\mathbf{M} \\
\mathbf{M} \\
\mathbf{M} \\
\mathbf{M} \\
\mathbf{M} \\
\mathbf{M} \\
\mathbf{F} \\
\mathbf{F} \\
\mathbf{F} \\
\mathbf{F} \\
\mathbf{F} \\
\mathbf{F}\end{array}$ & $\begin{array}{r}23 \\
5 \\
9 \\
16 \\
2 \\
1 \\
3 \\
16 \\
3 \\
3 \\
16 \\
6\end{array}$ & $\begin{array}{r}20 \\
45 \\
14 \\
8 \\
20 \\
27 \\
10 \\
30 \\
36 \\
14 \\
36 \\
24\end{array}$ \\
\hline
\end{tabular}

- Ritchie and others (1968).

\section{Results}

Fig. 1 shows the ${ }^{99} \mathrm{Tc}$ indices obtained from seven normal controls and twenty-nine patients with rheumatoid arthritis. There was a significant difference between the two groups studied $(t=2.6$; $P<0.02$ ).

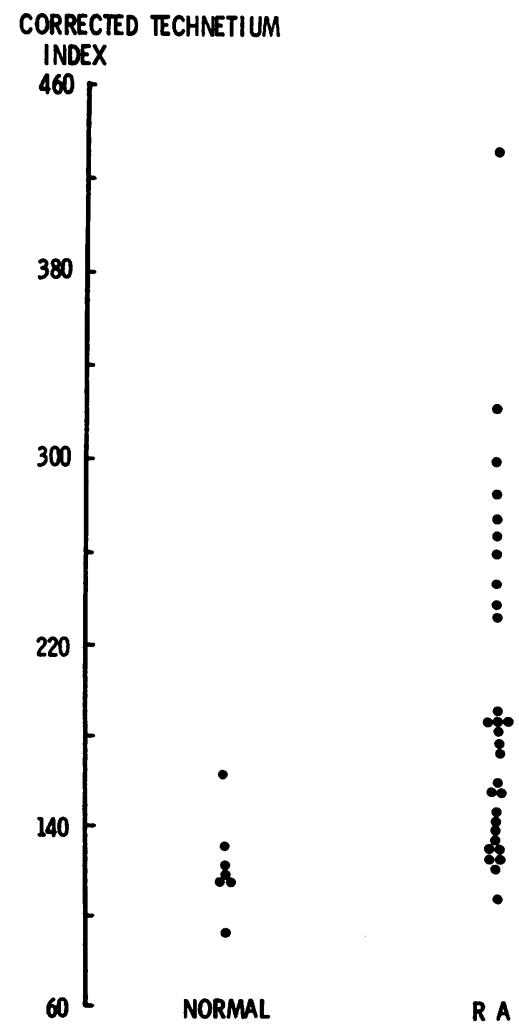

FIG. 1 Corrected ${ }^{99}$ Tc index in patients with $R A$ and normal controls

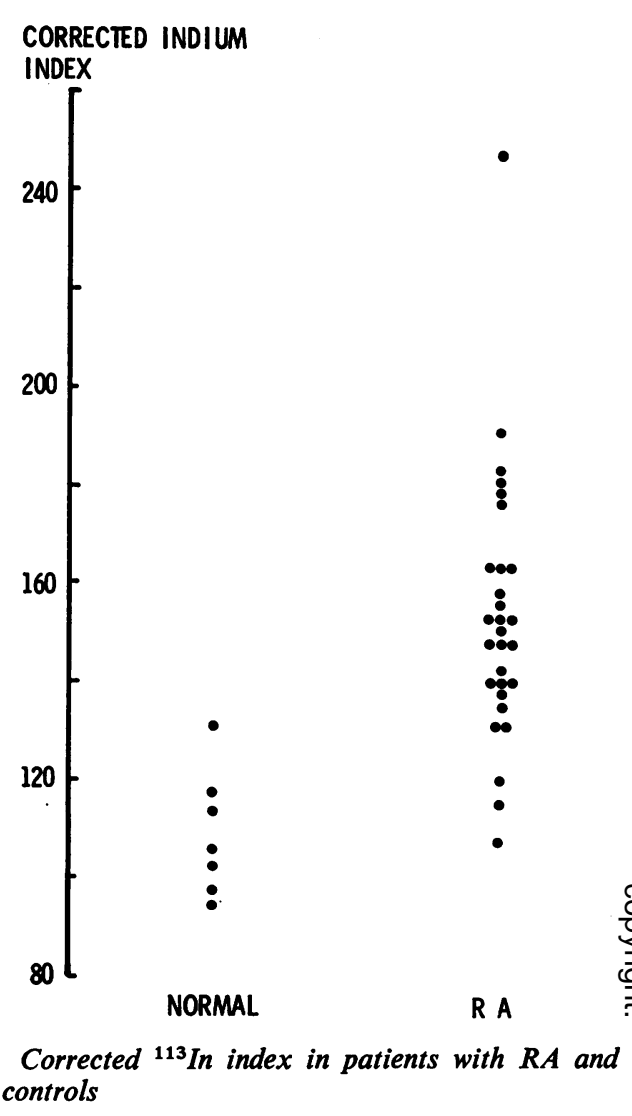

Fig. 2 shows the ${ }^{113}$ In indices obtained from seven normal controls and thirty patients with RA. There was a highly significant difference between the two groups studied $(t=4 \cdot 1 ; P<0.01)$.

A highly significant correlation was found between articular index and ${ }^{99} \mathrm{Tc}$ index $(r=0.6 ; \mathrm{t}=4.0$; $P<0.01$ ). No such correlation was found between articular index and ${ }^{113}$ In index $(r=-0.15 ; t=0.8$; $\mathbf{P}<0 \cdot 1)$.

Table II shows changes in pain, duration of morning stiffness, articular index, paracetamol consumption, joint size, and the two isotope indices at the end of the placebo and prednisolone weeks. There was a highly significant reduction in pain and joint size and a significant reduction in articular index on prednisolone. Changes in paracetamol consumption, duration of morning stiffness, ${ }^{99} \mathrm{Tc}$ index, and ${ }^{113} \mathrm{In}$ index were not statistically significant. Ten patients preferred prednisolone, one preferred placebo, and one had no preference, a significant difference $(\mathrm{P}<0.02)$.

\section{Discussion}

Oka, Rekonen, and Ruotsi (1971) showed a correlation between articular index and ${ }^{99} \mathrm{Tc}$ index; we 
Table II Mean measurements made after one week of treatment with either $15 \mathrm{mg}$ prednisolone daily or identical placebo

\begin{tabular}{|c|c|c|c|c|}
\hline & Prednisolone & Placebo & $t$ & $P$ \\
\hline Pain & $6 \cdot 42$ & $11 \cdot 83$ & $4 \cdot 091$ & $<0.01$ \\
\hline Duration of morning stiffness & $27 \cdot 91$ & $39 \cdot 58$ & 0.695 & $>0.1$ \\
\hline Articular index & 13 & $23 \cdot 67$ & $2 \cdot 67$ & $<0.05$ \\
\hline Joint size & $579 \cdot 67$ & $595 \cdot 58$ & $5 \cdot 655$ & $<0.01$ \\
\hline Paracetamol consumption & $17 \cdot 58$ & 31.08 & 1.795 & $>0.1$ \\
\hline Tc Index & 23,075 & 25,113 & $1 \cdot 026$ & $>0.1$ \\
\hline In index & 7,088 & 6,683 & 0.3322 & $>0.1$ \\
\hline
\end{tabular}

were again able to confirm this observation. Thus, ${ }^{99} \mathrm{Tc}$ index may be a useful measure of disease severity. Such a correlation was not found between articular index and ${ }^{113}$ In index, even though ${ }^{113}$ In appeared to have theoretical advantages as a measure of vascularity.

Neither isotope index was responsive to steroid therapy. It appears from these observations that joint scanning using these two isotopes has little value in the assessment of an anti-inflammatory compound, being less sensitive than conventional methods.

It was of interest that ${ }^{99} \mathrm{Tc}$ index proved to be a better index of inflammation than ${ }^{113}$ In index. ${ }^{99} \mathrm{Tc}$ appears to reflect not only vascularity but other features, possibly related to its distribution in the extravascular space.

\section{Summary}

Technetium and indium indices are higher in RA than in normals. There is a significant correlation between articular index and technetium index but not indium index. Neither technetium nor indium indices were responsive to treatment with prednisolone. These indices did not therefore represent an advantage over conventional methods.

We would like to thank Dr. H.W. Balme for permission to study patients under his care.

\section{References}

BerRy, H., AND Huskisson, E. C. (1972) Clin. Trials J., 9, 13 (Treatment of rheumatoid arthritis: a trial of meprothixol)

BoARdMan, P. L., AND HART, F. D. (1967) Brit. med. J., 4, 264 (Clinical measurement of the anti-inflammatory effects of salicylates in rheumatoid arthritis)

Committee of the American Rheumatism Association (1959) Ann. rheum. Dis., 18, 49 (Diagnostic criteria for rheumatoid arthritis, 1958 revision)

Dick, W. C., Neufeld, R. R., Prentice, A. G., Woodburn, A., Whaley, K., Nuki, G., ANd Buchanan, W. W. (1970) Ibid., 29, 135 (Measurement of joint inflammation: a radio-isotopic method)

HART, F. D., AND HUSKISSON, E. C. (1972) Lancet, 1, 28 (Measurement in rheumatoid arthritis)

Huskisson, E. C., Berry, H., Browett, J. P., AND Balme, H. W. (1973) Ann. rheum. Dis., 32, 99 (Measurement of inflammation. 2. Comparison of technetium clearance and thermography with standard methods in a clinical trial)

Oka, M., Rekonen, A., AND Ruotsi, A. (1971) Acta rheum. scand., 17, 27 (Tc-99m in the study of systemic inflammatory activity in rheumatoid arthritis)

Ritchie, D. M., Boyle, J. A., McInnes, J. M., Jasani, M. K., Dalakos, T. G., Grieveson, P., and Buchanan, W. W. (1968) Quart. J. Med., 37, 393 (Clinical studies with an articular index for the assessment of joint tenderness in patients with rheumatoid arthritis)

Stern, H. S., Goodwin, D. A., Scheffel, U., WAGNer, H. N., AND Kramer, H. H. (1967) Nucleonics, 25, 62 (In $113 \mathrm{~m}$ for blood-pool and brain scanning) 